\title{
23. PETROLOGY AND K-Ar AGE OF BASALTIC ROCKS, SITES 353, 354, AND 355, DSDP LEG 39
}

\author{
G.S. Kharin, Atlantic Branch of P.P. Shirshov Oceanology Institute \\ of the Academy of Sciences of the USSR, Kaliningrad \\ and \\ M.M. Arakeljanz and Y.I. Dmitriev, Institute of Geology of Ore Deposits, Mineralogy, \\ Petrography, and Geochemistry of the Academy of Sciences of the USSR, Moscow
}

\section{INTRODUCTION}

Fourteen samples (minicores) of basalts cored during Leg 39 of DSDP were made available to us for thinsection and chemical analysis, and for $\mathrm{K}-\mathrm{Ar}$ age determination. The samples are from the Vema Fracture Zone (Site 353), Ceará Rise (Site 354, and Brazil Basin (Site 355). Using our own data, together with the initial shipboard core description, we here present the petrography, mineralogy, and chemistry of these basalts, as well as their age and facies development, and compare them with other oceanic and terrestrial basalts.

\section{VEMA FRACTURE ZONE}

The Vema Fracture Zone is a transverse fracture along which the Mid-Atlantic Ridge is disengaged and displaced for $300 \mathrm{~km}$. Detailed topographic and geologic investigations of the fracture zone have been carried out by van Andel et al. (1967, 1969, 1971); Bonatti et al. (1970-1971); Bonatti (1973); Melson and Thompson (1971); and Thompson and Melson (1972). The fracture zone is topographically a narrow, transverse valley filled with up to a kilometer of Pleistocene and Recent sediments, with a transverse ridge adjacent to the southern segment of the MidAtlantic Ridge (Figure 1, inset). Dredge hauls from the northern wall of the valley show it to consist in its upper part primarily of basalts, while the lower part includes serpentinized peridotites, gabbro, and amphibolites, probably related to layer 3 of the oceanic crust (Figure 1). According to Bonatti (1973) the transverse ridge is a protrusion of serpentinized peridotite of mantle origin, but includes also gabbro, basalt, greenstone, and amphibolite, as well as breccias and phosphorites.

Two drill sites were proposed for the fracture zone. The first was to obtain a section of the lower oceanic crust at the foot of the northern wall of the fracture zone. The second was to sample the serpentinite mantle protrusions at the foot of the southern wall. Because of mechanical failure, these objectives were unfortunately not achieved. The actual rocks recovered in Holes 353 , $353 \mathrm{~A}$, and 353B, consist of aphyric and sparsely porphyritic basalts and hyalo-basalts along with olivine basalts with variable amounts (5\% and greater) of modal olivine (Table 1). The basalts are relatively fresh and the negligible amount of secondary mineral alteration attests to their young age. Variolitic and broom-like textures suggest crystallization under rapid chilling (Figure 2). The varioles and broom-like structures appear to be of more leucocratic (acid) composition than the poorly crystallized, glassy groundmass. The boundaries of varioles are indistinct, with a gradual transition to the groundmass. The varioles and "brooms" consist of thin, skeletal laths of calcic plagioclase up to $2 \mathrm{~mm}$ long and with split ends. Poorly crystallized and xenomorphic crystals of clinopyroxene (augite) occur within and between varioles. Calcite pseudomorphs of euhedral olivine and round amygdules perforated by calcite are common.

The groundmass comprises up to $87 \%$ of thin-section area and consists of glass with microlites. Its composition, as indicated by index of refraction $(\mathrm{n}=$ 1.586-1.595), corresponds to that of a tholeiitic magma with approximately $50 \% \mathrm{SiO}_{2}$.

Based on analysis of two samples from Hole 353B (analyses 1 and 2 of Table 2) the basalts are chemically relatively homogeneous. They are low-potassic basalts similar in composition to the average Mid-Atlantic Ridge basalt of Melson et al. (1968) and dredged basalts of the Vema Fracture Zone (Melson and Thompson, 1971). Poor crystallization, and the presence of variolites and hyalobasalts suggest that the Site 353 basalts are typical oceanic tholeiites of young age (Figure 3).

\section{CEARA RISE}

Ceará Rise is situated on the abyssal plain in the vicinity of the northeast continental slope of South America. The analogous Sierra Leone Rise is on the opposite side of the Atlantic adjacent to the African continental slope. Both rises are without the magnetic stripes that characterize normal oceanic crust, and one of the major objectives of drilling on the Ceará Rise was to determine the nature of basement here.

Site 354 is on the northwestern edge of Ceará Rise. Acoustic basement here, penetrated to a depth of 14 meters, lies beneath upper Cretaceous sediments, 886 meters below the sea floor. According to the shipboard description, basement consists of light gray "diabasic and doleritic basalts" with yellow spots in the upper part of the section and dark grayish spots in the lower part. Calcite veins up to a centimeter in thickness are abundant. The basalts are coarse grained and well crystallized, and features suggestive of rapid chilling are 


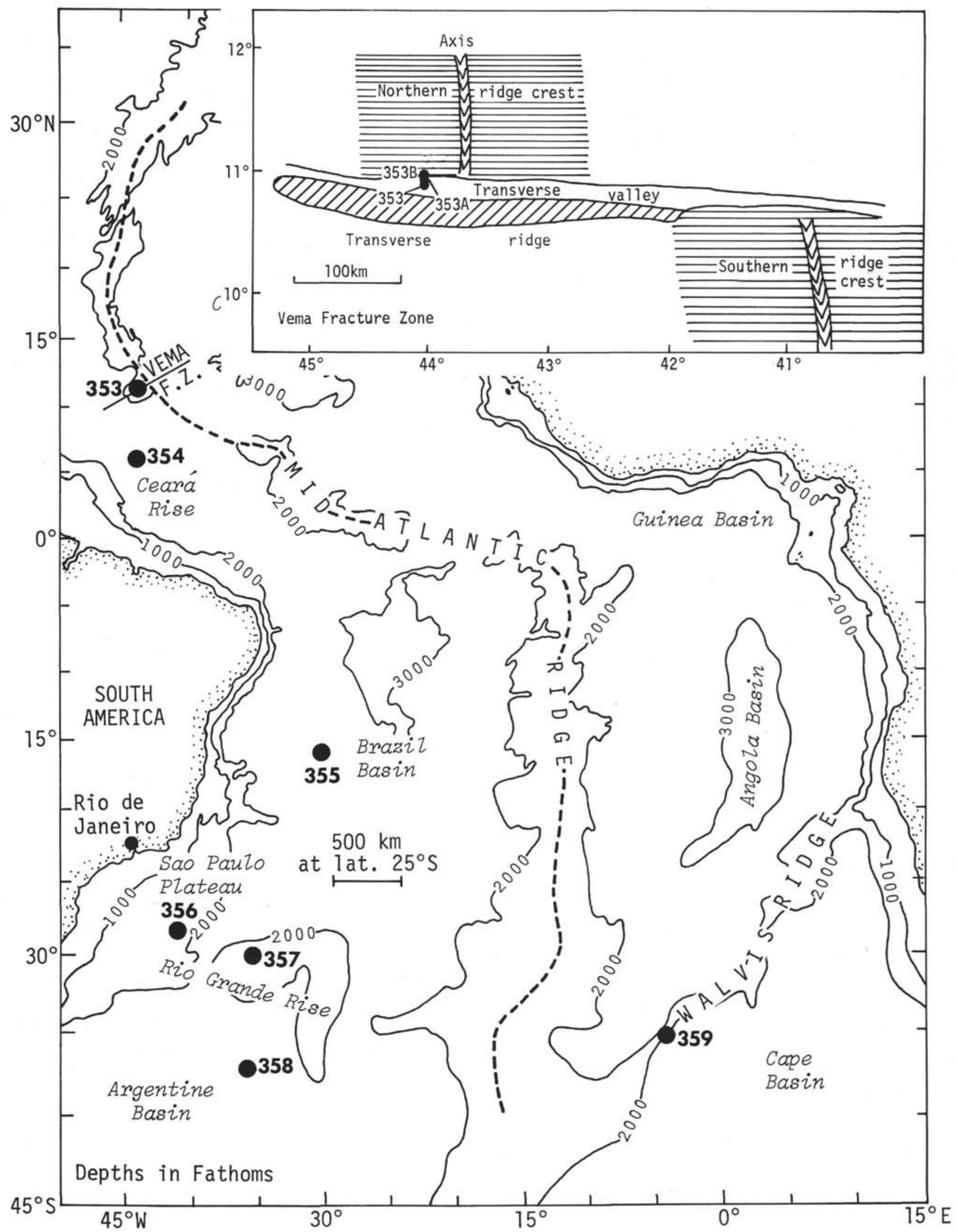

Figure 1. Leg 39 sites, from which basalts were studied. Based on Bonatti et al., 1971. 
TABLE 1

Mineral Composition of Magmatic Rocks of Holes 353A, 353B, and Site 354, DSDP Leg 39

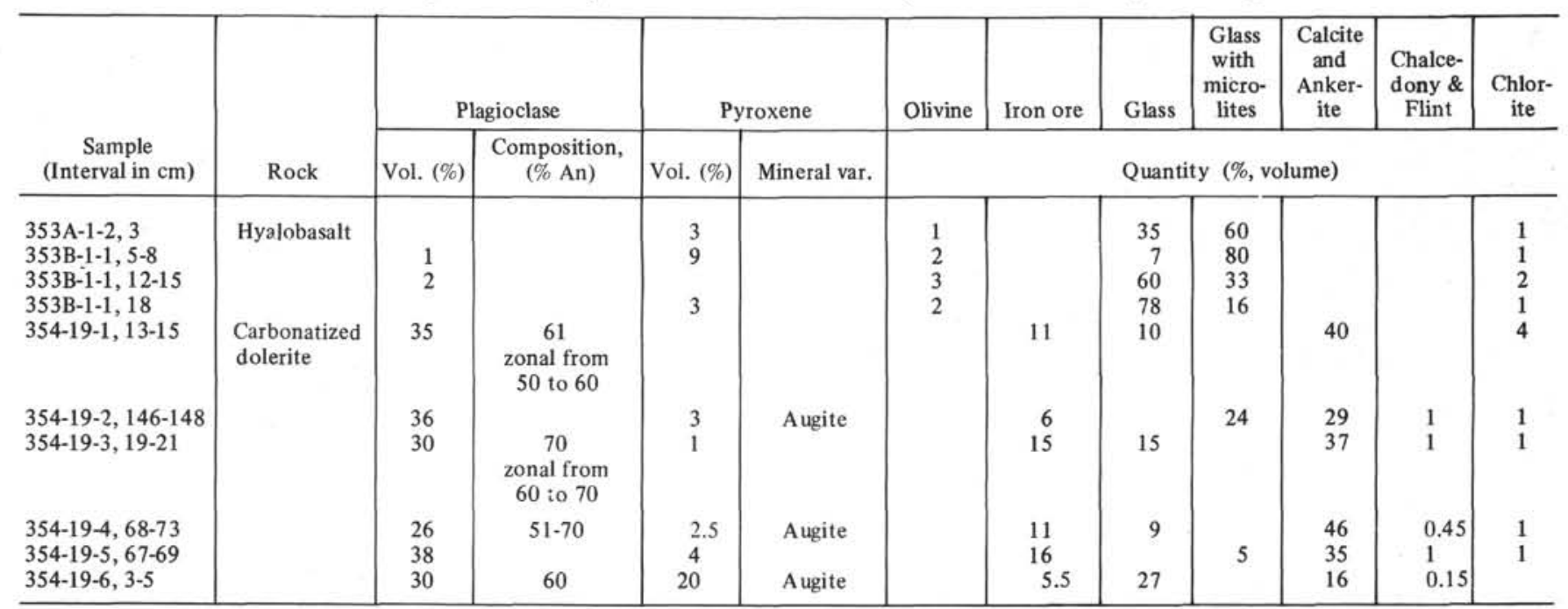

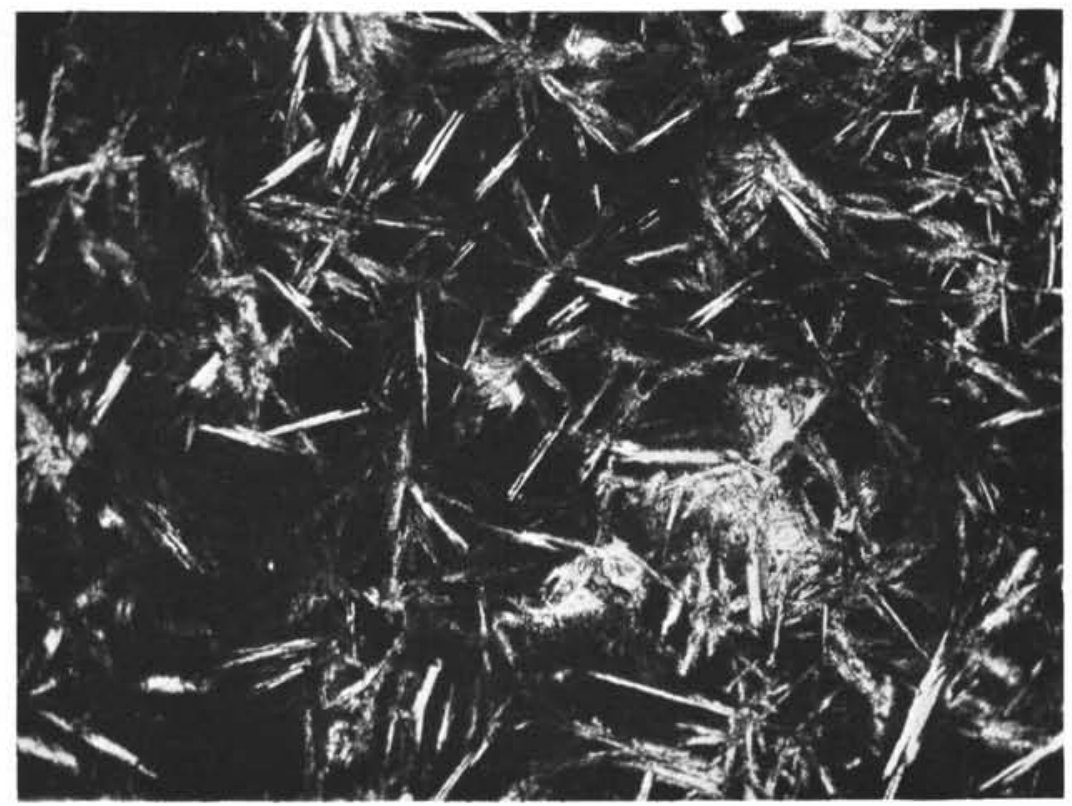

Figure 2. Hyalobasalt. The beginning of formation of plagioclase net and broom-like aggregates of plagioclase laths. Plane-polarized light, $\times 70$. Sample 353A-1-2, 3-5 cm.

absent. In thin section, poorly crystallized glass with microlites of plagioclase and pyroxene is only rarely seen (e.g., Sample 354-19-4, 68-73 cm). It is therefore likely that these rocks are part of a sill or thick flow. The rocks here can be described as carbonatized dolerites (Figure 4). The structural lattice of the rocks consists of prismatic laths of plagioclase (up to $2 \mathrm{~mm}$ in length), with subophitic orientation. The plagioclase is polysynthetically twinned and ranges in composition from $A_{n}$ to $A_{70}$ (by determination of the angle of extinction perpendicular to [010]). In zoned plagioclase phenocrysts, composition ranges from $\mathrm{An}_{50}$ to $\mathrm{An}_{60}$ (Sample 354-19-1, 13-15 cm) and An60 to An70 (Sample $354-19-3,19-21 \mathrm{~cm})$. Determination of index of refraction indicates the presence of more acidic plagioclase, andesine, in Sample 354-19-6, 99-101 cm $(\mathrm{Ng}[\gamma]=1.559, \mathrm{~Np}[\alpha]=1.551)$, which corresponds to a composition of An45.

Crystallized mesostastis occurs between compositional boundaries of plagioclase crystals, and the interstices between plagioclase crystals, filled with decomposed pyroxene (augite, $\mathrm{Ng}[\gamma]=48^{\circ}$ ), were observed. The proportion of ore minerals, probably magnetite and ilmenite, in the form of anhedral and skeletal crystals, is high (up to $16 \%$; see Table 1 and Figure 5).

Secondary minerals are abundant and diverse. Carbonates, represented by calcite and ankerite, prevail. Calcite replaces plagioclase and is scattered in the form of amygdule-filling veins. Ankerite $\left(n_{\mathrm{o}}=\right.$ 
TABLE 2

Chemical Analyses (wt. \%) of Magmatic Rocks of Holes 353B and 354, DSDP Leg 39

\begin{tabular}{|c|c|c|c|c|c|c|c|c|c|c|c|c|}
\hline \multirow[b]{2}{*}{$\mathrm{SiO}_{2}$} & \multirow{2}{*}{$\frac{1}{49.97}$} & \multirow{2}{*}{$\frac{2}{49.62}$} & \multirow{2}{*}{$\frac{3}{50.09}$} & \multirow{2}{*}{$\begin{array}{c}4 \\
49.21\end{array}$} & \multicolumn{2}{|c|}{5} & \multicolumn{2}{|c|}{6} & \multicolumn{2}{|c|}{7} & \multicolumn{2}{|c|}{8} \\
\hline & & & & & 38.29 & 44.12 & 40.19 & 45.64 & 40.89 & 46.41 & 42.07 & 46.36 \\
\hline $\mathrm{TiO}_{2}$ & 1.77 & 1.77 & 1.39 & 1.39 & 3.94 & 4.54 & 3.96 & 4.47 & 3.32 & 3.77 & 3.39 & 3.73 \\
\hline $\mathrm{Al}_{2} \mathrm{O}_{3}$ & 16.03 & 15.83 & 16.44 & 15.81 & 13.32 & 15.34 & 13.10 & 14.88 & 13.13 & 14.90 & 12.84 & 14.14 \\
\hline $\mathrm{Fe}_{2} \mathrm{O}_{3}$ & 4.17 & 3.97 & 1.46 & 2.21 & 7.15 & 8.24 & 4.72 & 5.36 & 4.92 & 5.58 & 5.32 & 5.86 \\
\hline $\mathrm{FeO}$ & 5.53 & 6.27 & 8.60 & 7.19 & 8.94 & 10.30 & 8.76 & 9.95 & 7.01 & 7.95 & 9.03 & 9.95 \\
\hline $\mathrm{MnO}$ & 0.19 & 0.19 & 0.17 & 0.16 & 0.25 & 0.29 & 0.22 & 0.25 & 0.27 & 0.30 & 0.25 & 0.27 \\
\hline $\mathrm{MgO}$ & 8.08 & 7.87 & 7.26 & 8.53 & 4.24 & 4.88 & 3.75 & 4.26 & 3.43 & 3.89 & 5.58 & 6.14 \\
\hline $\mathrm{CaO}$ & 10.26 & 10.82 & 10.98 & 11.14 & 7.16 & 8.25 & 9.58 & 10.88 & 10.88 & 12.26 & 8.60 & 9.47 \\
\hline $\mathrm{Na}_{2} \mathrm{O}$ & 2.72 & 2.66 & 2.84 & 2.71 & 2.56 & 2.95 & 2.66 & 3.02 & 2.92 & 3.31 & 2.66 & 2.93 \\
\hline $\mathrm{K}_{2} \mathrm{O}$ & 0.18 & 0.15 & 0.11 & 0.26 & 0.59 & 0.68 & 0.72 & 0.81 & 1.01 & 1.14 & 0.60 & 0.66 \\
\hline $\mathrm{P}_{2} \mathrm{O}_{5}$ & 0.17 & 0.16 & 0.11 & 0.15 & 0.34 & 0.40 & 0.39 & 0.44 & 0.38 & 0.43 & 0.41 & 0.45 \\
\hline n. n. n. & 0.31 & 0.25 & 0.45 & & 12.55 & & 11.63 & & 10.84 & & 8.18 & \\
\hline Total & 99.38 & 99.55 & & & 99.33 & & 99.70 & & 99.42 & & 99.43 & \\
\hline $\mathrm{S}$ & 0.06 & 0.12 & & & 0.30 & & 0.18 & & 0.20 & & 0.36 & \\
\hline $\mathrm{CO}_{2}$ & 0.30 & 0.13 & & & 10.87 & & 10.30 & & 10.82 & & 7.63 & \\
\hline
\end{tabular}

NOTE: 1 = hyalobasalt, Sample 353B-1-1, 3-5 cm: 2 = hyalobasalt, Sample 353B-1-1, $15-18 \mathrm{~cm}: 3$ = average composition of the Vema Fracture Zone Basalts (Melson and Thompson, 1971): 4 = average composition of the MidAtlantic Ridge Basalts (Melson et al., 1968): 5-8 = carbonitized dolerite of Ceará Rise, Site 354 (the left column usual analyses, the right column - evaluated analyses): 5 = Sample 354-19-1, 13-15 cm: 6 = Sample 354-19-3: 19-21 cm: 7 = Sample $354-19-4,68-73 \mathrm{~cm}: 8$ = Sample 354-19-6, 3-5 cm.

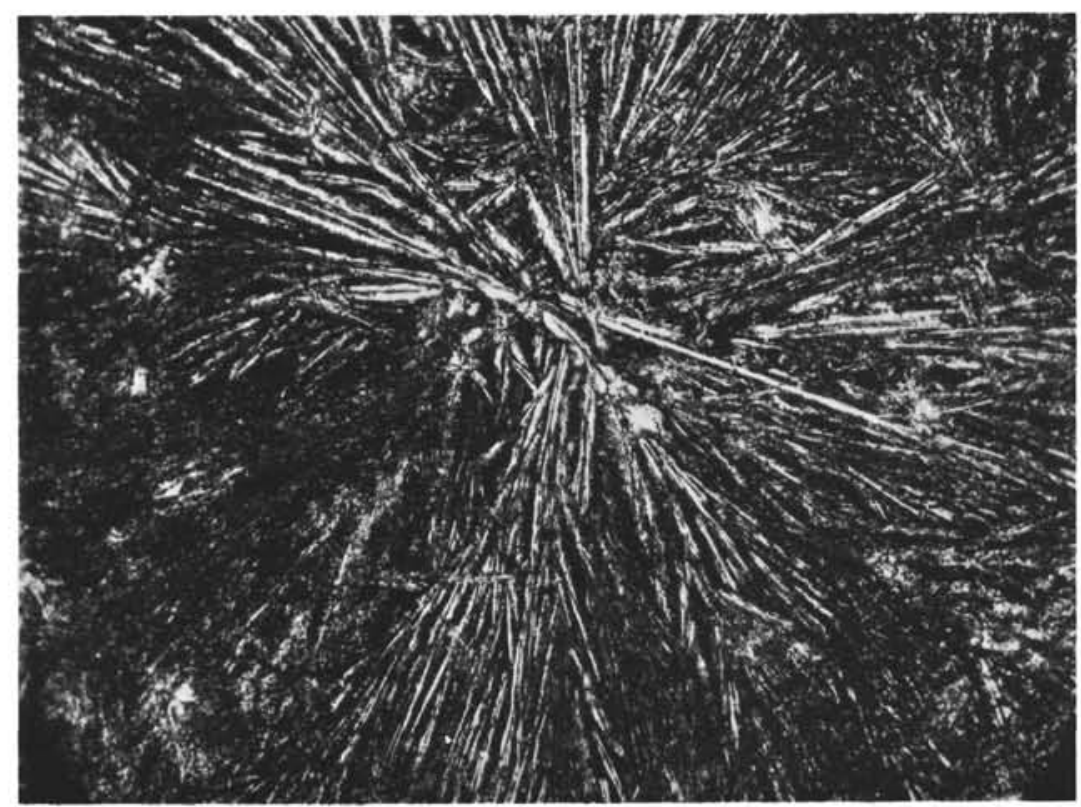

Figure 3. Hyalobasalt. Radially fibrous texture of varioles, consisting of skeletal plagioclase laths. Fine crystals of olivine. Plane-polarized light, $\times 70$, Sample 353B-1-1, 12-15 cm.

1.698; $\left.n_{\mathrm{e}}=1.513\right)$, in the form of fine-grained aggregates, replaces pyroxene. Pyroxene is also replaced by colorless, radially beamed amphibole and fine-grained aggregates of goethite. Pyrite occurs as minute cubic crystals and thin veins. Chalcedony and flint occur in calcitic veins and as replacements of calcite amygdules.

Judging from the analysis of four samples of the dolerite, secondary mineralization has considerably altered its initial composition. The low silica content $(38.3 \%-42.1 \%)$ is due to carbonatization, with replacement of aluminosilicates by calcite and ankerite, and consequent decrease in $\mathrm{Al}_{2} \mathrm{O}_{3}$ and increase in $\mathrm{CaO}$ and $\mathrm{Fe}$.

In order to exclude the effects of secondary mineralization on the composition of the dolerite, we evaluated its "dry" mass, excluding the components lost on ignition (LOI). Such an evaluation is possible 


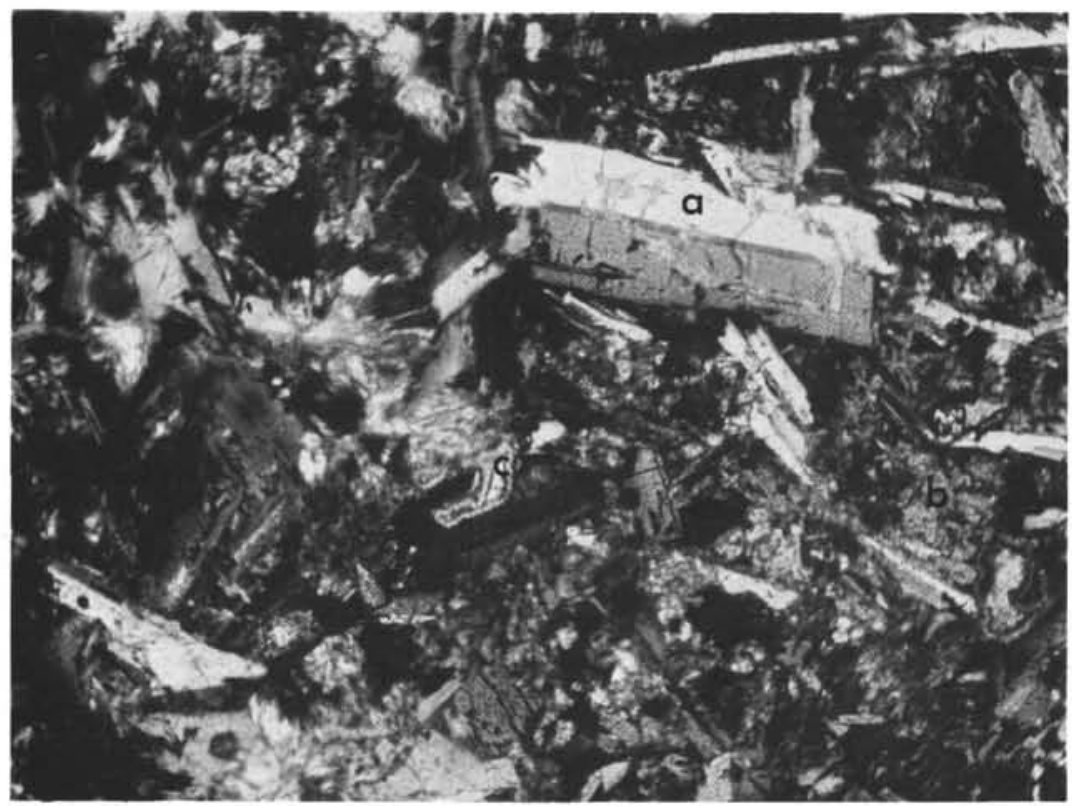

Figure 4. Carbonatizated dolerite. Coarse plagioclase lathes (a), clinopyroxene relicts (b), irregular carbonate aggregates (c). Crossed nicols. $\times$ 35. Sample 354-19-5, 67-69 cm.

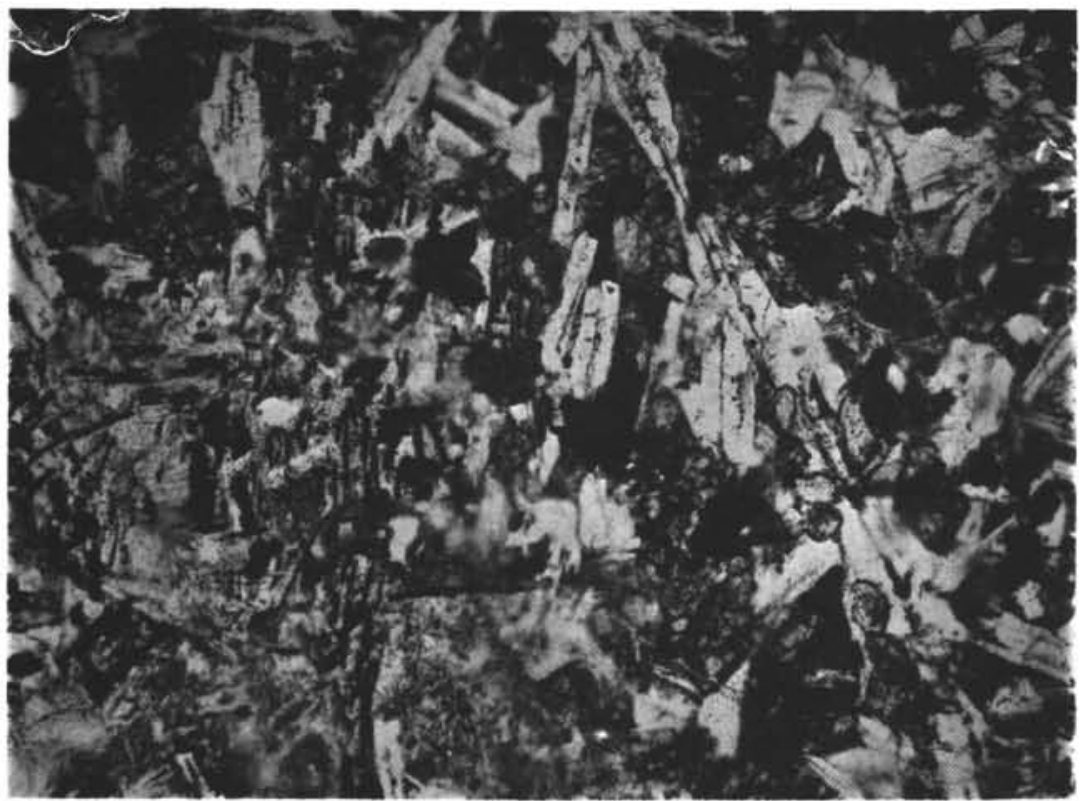

Figure 5. Carbonatized dolerite. There is a large number of ore minerals, represented by isometric crystals of magnetite and plate crystals of ilmenite. Plane-polarized ligth, $\times 35$. Sample 354-19-5, 67-69 cm.

because the LOI components consist almost entirely of carbon dioxide. As a tentative hypothesis, we suggest that the secondary mineralization is a result of carbonic acid emanations without a concomitant loss of the other rock-forming oxides.

The "dry" composition of the four samples analyzed, summed to $100 \%$, is given in the right-hand column in Table 2. The high titanium content (up to $4.47 \%$ ) and iron oxides (up to $5.86 \% \mathrm{Fe}_{2} \mathrm{O}_{3}$ and $9.95 \% \mathrm{FeO}$ ) is significant. This, plus a higher potash content (up to $1.14 \% \mathrm{~K}_{2} \mathrm{O}$ ), a high ratio of $\mathrm{K}_{2} \mathrm{O}$ to $\mathrm{Na}_{2} \mathrm{O}(0.3-0.5)$, and low content of magnesia, suggests that these rocks are not typical of oceanic tholeiites, but are closer to more deep-seated alkali basalts in composition. Their composition is similar to that of plateau basalts of several islands and seamounts (Feden, 1966; NoeNygaard, 1966; Thompson and Melson, 1972), and to alkali basalts recovered during DSDP Leg 14 (Sites 137 
and 138) near the African continental slope (Wright et al., 1972). The latter, however, are slightly poorer in titanium and iron than the present rocks.

The Ceará Rise basalts, in their high contents of alkalis, titanium, and iron, approach in composition the average alkali-rich basalts of the Atlantic (Engel and Engel, 1968), but they are richer in iron and titanium. This iron and titanium content may be attributable to the metasomatic leaching of silica, magnesium, and probably aluminum, leaving a residue of more stable compounds of iron and titanium.

\section{K-Ar AGE DETERMINATIONS}

$\mathrm{K}-\mathrm{Ar}$ ages were determined for two samples, the dolerite from Site 354 on the Ceará Rise, and variolitic basalt from Site 355 in the Brazil Basin. Descriptions of these rocks follow.

The dolerite (Sample 354-19-3, 88-92 cm) is a browngray, fine-grained rock with tholeiitic to ophitic texture. It is strongly carbonatized. Plagioclase amounts to $37 \%$ of the rock and has a composition of Anss. Relics of clinopyroxene make up to $5 \%$; ore minerals, $13 \%$; carbonates, $20 \%$; quartz, $1 \%$, and tholeiitic mesostasis, $24 \%$. Rare pseudomorphs of calcite after olivine, and grains of orthorhombic pyroxene occur. Albite is present, apparently in the tholeiitic mesastasis. Carbonates replace the major rock-forming minerals, and occur in grain interstices and veins. Chlorite and quartz are also found in grain interstices.

The basalt sample $(355-22-3,104-108 \mathrm{~cm})$ is gray, variolitic, with amygdaloidal texture (Figure 6). The cryptocrystalline groundmass contains fibrous, radial aggregates of plagioclase, grains of clinopyroxene, and tiny exsolution grains of ore minerals. Needles of colorless amphibole occur, along with chlorite-filled amygdules.

\section{ANALYTICAL METHODS}

Potassium and radiogenic argon were determined in the Laboratory of Geochronology of the Institute of Geology of Ore Deposits, Petrography, Mineralogy, and Geochemistry, Academy of Sciences of the USSR. Analytical results are presented in Table 3.

The 30-60 mesh fraction of ground whole-rock samples was used. After homogenization and reduction, the samples were divided in four parts. Two were used for the determination of radiogenic argon, and one was powdered for potassium analysis.

Potassium was determined by flame photometry. Two samples of standards, one with an excess and one with a deficit of potassium, were analyzed along with each dated sample. A buffer solution of $25 \mathrm{~g} / 1$ of $\mathrm{MgCl}_{2}$ was used.

Argon analyses were done using isotope dilution techniques with the addition of an $\mathrm{Ar}^{38}$ tracer, using a highly sensitive $60^{\circ}$ sector mass spectrometer with a 200 $\mathrm{mm}$ orbit radius. The $\mathrm{K}^{40}$ decay constants used were: $\lambda_{\mathrm{e}}$ $=0.557 \times 10^{-10}$ year $^{-1}$ and $\lambda \beta=4.72 \times 10^{-10}$ year $^{-1}$. The atomic abundance of $\mathrm{K}^{40}$ used was $1.19 \times 10^{-4}$ mole/mole.

The errors in argon and potassium content listed are the mean value of the standard error at the $65 \%$ confidence level. The error in age determination is the mean value of the error at the $90 \%$ confidence level.

\section{REFERENCES}

Bonatti, E., 1973. Origin of the offsets of the Mid-Atlantic Ridge in fracture zones: J. Geol., v. 81, p. 144-156.

Bonatti, E., Honnores, I. and Ferrara, G., 1970. Equatorial Mid-Atlantic Ridge: petrolic and $\mathrm{Sr}$ isotopic evidence for an Alpine-type rock assemblage: Earth Planet. Sci. Lett., v. 9 , p. $247-256$.

1971. Peridotite-gabbro-basalt complex from the equatorial Mid-Atlantic Ridge: Phil. Trans. Roy. Soc. London, Ser. A, v. 268, p. 385-402.

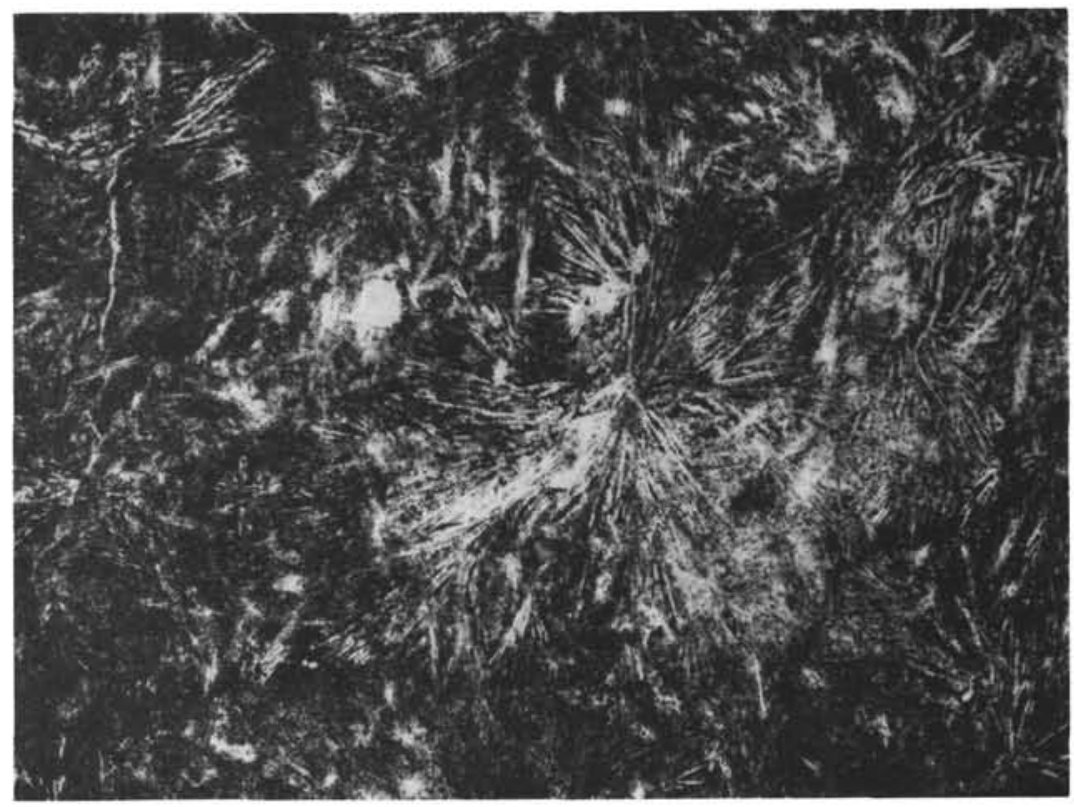

Figure 6. Variolitic amygdaloidal basalt. Plane-polarized light, $\times 70$. Sample $355-22-3,104-108 \mathrm{~cm}$. 
TABLE 3

K-Ar Dating, Leg 39 Samples

\begin{tabular}{|c|c|c|c|c|c|}
\hline $\begin{array}{c}\text { Sample } \\
\text { (Interval in } \mathrm{cm} \text { ) }\end{array}$ & $\begin{array}{l}\text { Material } \\
\text { Dated }\end{array}$ & $\begin{array}{l}K \\
(\%)\end{array}$ & $\begin{array}{c}{ }^{40} \text { Ar Rad. } \\
\text { (mole/g) }\end{array}$ & $\frac{{ }^{40} \mathrm{Ar} \text { Rad. }}{{ }^{40} \text { Ar Total }}$ & $\begin{array}{c}\text { Age } \\
(\mathrm{m} . \mathrm{y} .)\end{array}$ \\
\hline \multirow{3}{*}{$\begin{array}{l}354-19-3, \\
88-92\end{array}$} & \multirow{3}{*}{$\begin{array}{l}\text { Dolerite } \\
\text { (whole } \\
\text { rock) }\end{array}$} & 0.689 & $7.78 \times 10^{-11}$ & 19.6 & \multirow{5}{*}{$66 \pm 6$} \\
\hline & & 0.697 & $7.83 \times 10^{-11}$ & 23.2 & \\
\hline & & $\overline{0.69 \pm 0.02}$ & \multicolumn{2}{|c|}{$\overline{(7.80 \pm 0.40)} \times 10^{-11}$} & \\
\hline \multirow{3}{*}{$\begin{array}{l}355-22-3 \\
104-108\end{array}$} & \multirow{3}{*}{$\begin{array}{l}\text { Basalt } \\
\text { (whole } \\
\text { rock) }\end{array}$} & 0.522 & $3.35 \times 10^{-11}$ & 11.2 & \\
\hline & & 0.521 & $3.18 \times 10^{-11}$ & 18.1 & \\
\hline & & $\overrightarrow{0.52 \pm 0.02}$ & \multicolumn{2}{|c|}{$(3.27 \pm 0.20) \times 10^{-11}$} & $37 \pm 4$ \\
\hline
\end{tabular}

Engel, A.E.J. and Engel, C.G., 1968. The rocks of oceanic bed, Cardinal Problems of Oceanology: Moscow (Nauka), p. 183-217.

Feden, R.H., 1966. Volcanic rock from Caryn seamount: J. Geophys. Res., v. 71, p. 1761-1763.

Melson, W.G. and Thompson, G., 1971. Petrology of a transform fault zone and adjacent ridge sediments. Phil. Trans. Roy. Soc. London, v. 268, p. 432-441.

Melson, W.G., Thompson, G., and van Andel, T.H., 1968. Volcanism and metamorphism in the Mid-Atlantic Ridge, $22^{\circ} \mathrm{N}$ latitude: J. Geophys. Res., v. 73, p. 5925-5942.

Noe-Nygaard, A., 1966. Chemical composition of tholeiitic basalts from the Wyville-Thompson ridge belt: Nature, v. 212 , p. $60-62$.

Thompson, G. and Melson, W.G., 1972. The petrology of oceanic crust across fracture zones in the Atlantic ocean: evidence of a new kind of sea-floor spreading: J. Geol., v. 80 , p. $526-538$.
Van Andel, T.H., Corliss, J.B., and Bowen, V.T., 1967. The intersection between the Mid-Atlantic Ridge and the Vema Fracture Zone in the North Atlantic: J. Marine Res., v. 25, p. 343-351.

Van Andel, T.H., Phillips, J.D., and Von Herzen, R.P., 1969. Rifting origin for the Vema Fracture Zone in the North Atlantic: Earth Planet. Sci. Lett., v. 5, p. 296-300.

Van Andel, T.H., Von Herzen, R.P., and Phillips, J.D., 1971. The Vema Fracture Zone and the tectonics of tranverse shear zones in oceanic crustal plates: Mar. Geophys. Res., v. 3, p. 251-283.

Wright, T.L., Benson, W.E., Melson, W.G., and Hart, S.R., 1972. Petrology of basaltic rocks collected from Leg 14. In Hayes, D.E., Pimm, A.C., et al., Initial Reports of the Deep Sea Drilling Project, Volume 14: Washington (U.S. Government Printing Office), p. 767-772. 